\title{
Training on making wreaths for disability
}

\author{
Hairani Siregar ${ }^{1 *}$, Bengkel Ginting ${ }^{1}$ \\ ${ }^{1}$ Fakultas Ilmu Sosial dan Politik, Universitas Sumatera Utara, Medan \\ *hairani_fisipusu@yahoo.co.id
}

\begin{abstract}
This Community Service Program is one of the efforts made so that people with disabilities can be economically independent by providing skills training. The skills training provided is a skill that is tailored to the interests and types of disability. One type of skills provided is training in making bouquets. Flower wreath making services at this time, especially in big cities like Medan City are needed. The results of this training the participants were able to make a bouquet of flowers according to the trainer's team. This training makes the disabilities as trainees have economic resources for survival both as family members and family heads.
\end{abstract}

Keyword: Training, Floral Arrangements, People With Disabilities

\begin{abstract}
Abstrak
Program kegiatan Pengabdian Kepada Masyarakat ini sebagai salah satu usaha yang dilakukan agar penyandang disabilitas dapat mandiri secara ekonomi yaitu dengan memberikan pelatihan keterampilan. Pelatihan keterampilan yang diberikan adalah keterampilan yang disesuaikan dengan minat dan jenis kedisabilitasannya. Salah satu jenis ketrampilan yang diberikan adalah pelatihan pembuatan karangan bunga. Jasa pembuatan karangan bunga pada saat ini khususnya di kota-besar seperti Kota Medan sangat dibutuhkan. Hasil pelatihan ini peserta telah mampu membuat karangan bunga sesuai pesanan tim pelatih. Pelatihan ini menjadikan para disabilitas sebagai peserta pelatihan memiliki sumber ekonomi untuk kelanjutan hidup baik sebagai anggota keluarga maupun kepala keluarga.
\end{abstract}

Kata Kunci: Pelatihan, Karangan Bunga, Penyandang Disabilitas

\section{PENDAHULUAN}

\subsection{Analisis Situasi}

Indonesia dalam melaksanakan pembangunan nasionalnya selalu dilandasi oleh tujuan untuk penciptaan keadilan dan kemampuan bagi seluruh rakyat. Salah satu diantaranya adalah "Pembangunan Kesejahteraan Sosial". Pembangunan kesejahteraan sosial merupakan usaha yang terencana dan terarah yang meliputi berbagai bentuk intervensi dan pelayanan sosial untuk memenuhi kebutuhan manusia, mencegah dan mengatasi masalah sosial, serta memperkuat institusiinstitusi sosial (Edi Suharto, 1997: 97). Pengertian tersebut berarti bahwa tujuan pembangunan kesejahteraan sosial mencakup seluruh masyarakat dan Bangsa Indonesia termasuk warga masyarakat yang menyandang masalah kesejahteraan sosial. Salah satu penyandang masalah kesejahteraan sosial sebagai sasaran dari pembangunan kesejahteraan sosial yaitu orang-orang yang berstatus penyandang disabilitas. (Depsos RI, 1996:17).

Penyandang disabilitas dapat diartikan manusia yang mempunyai keterbatasan fisik, mental atau intelektual yang dapat mengganggu atau menjadi rintangan dan hambatan baginya untuk melakukan kegiatan secara layak Penyandang disabilitas memiliki keterbatasan fisik seperti cacat tubuh bawaan lahir, mengidap penyakit polio dan amputasi.

Memiliki kekurangan fisik bukan berarti penyandang disabilitas tidak bisa mengerjakan sesuatu, dengan adanya kekurangan tersebut, diharapkan agar penyandang disabilitas tidak tersisihkan dari pergaulan dan peranannya dalam masyarakat. Penyandang disabilitas merupakan kelompok masyarakat yang selama ini termarginalisasikan dan sering didiskriminasikan dalam kehidupan bermasyarakat. Mereka seringkali diabaikan dan tidak dianggap keberadaannya baik oleh keluarga, masyarakat bahkan negara. Banyak orang tua yang masih menyembunyikan anaknya yang merupakan penyandang disabilitas, perlakuan dari lingkungan dan masyarakat yang sinis, melihat 
penyandang disabilitas sebagai makhluk lemah dan hanya merupakan beban bagi keluarga dan masyarakat. Masih kurangnya perhatian pemerintah atau negara terhadap penyandang disabilitas membuat kondisinya semakin terpuruk dan terpinggirkan. Walaupun saat ini pemerintah telah menetapkan berbagai kebijakan terkait dengan kehidupan dan keberadaan penyandang disabilitas, akan tetapi pelaksanaannya masih jauh dari apa yang diharapkan. Hal ini disebabkan masih adanya pemahaman yang berbeda terhadap penyandang disabilitas oleh berbagai Stake Holder, sehingga implementasi dari berbagai kebijakan tersebut selalu tidak menyentuh sisi penting kehidupan.

Menurut International Labour Organization (konvensi PBB mengenai hak-hak Disabilitas) atau disingkat dengan UNCRPD Tahun 2011, yaitu sebuah organisasi internasional yang berperan aktif lebih dari lima puluh tahun dalam memperjuangkan hak-hak disabilitas, menurut mereka fakta yang terjadi saat ini adalah : 1. Sekitar 15 persen dari jumlah penduduk di dunia adalah penyandang disabilitas, lebih dari satu miliar orang. Mereka terbilang kelompok minoritas terbesar di dunia. 2. Sekitar 82 persen dari penyandang disabilitas berada di negara-negara berkembang dan hidup di bawah garis kemiskinan dan kerap kali. Menghadapi keterbatasan akses atas kesehatan, pendidikan, pelatihan dan pekerjaan yang layak. 3. Penyandang disabilitas tergolong lebih rentan terhadap kemiskinan di setiap negara, baik diukur dengan indikator ekonomi tradisional seperti PDB atau, secara lebih luas, dalam aspek keuangan non-moneter seperti standar hidup, misalnya pendidikan, kesehatan dan kondisi kehidupan. 4. Penyandang disabilitas perempuan memiliki risiko lebih besar dibandingkan penyandang disabilitas laki-laki. Kemiskinan mereka terkait dengan sangat terbatasnya peluang mereka atas pendidikan dan pengembangan keterampilan. 5. Hampir sebanyak 785 juta perempuan dan laki-laki dengan disabilitas berada pada usia kerja, namun mayoritas dari mereka tidak bekerja. Mereka yang bekerja umumnya memiliki pendapatan yang lebih kecil dibandingkan para pekerja yang non-disabilitas diperekonomian informal dengan perlindungan sosial yang minim atau tidak sama sekali. 6. Para penyandang disabilitas kerap kali terkucilkan dari pendidikan, pelatihan kejuruan dan peluang kerja. 7. Lebih dari 90 persen anak-anak dengan disabilitas di negara-negara berkembang tidak bersekolah (UNESCO) sementara hanya 1\% perempuan disabilitas bisa membaca (UNDP).

Kepedulian pemerintah terhadap penyandang disabilitas tersebut terlihat dengan adanya Undang-undang No. 8 Tahun 2016 Tentang Penyandang Disabilitas pada bagian keempat mengenai Pekerjaan, Kewirausahaan, dan Koperasi. Pada pasal 53 yang berbunyi : 1. Pemerintah, Pemerintah Daerah, Badan Usaha Milik Negara, dan Badan Usaha Milik Daerah wajib mempekerjakan paling sedikit 2\% (dua persen) Penyandang Disabilitas dari jumlah pegawai atau pekerja. 2. Perusahaan swasta wajib mempekerjakan paling sedikit 1\% (satu persen) Penyandang Disabilitas dari jumlah pegawai atau pekerja.

Berdasarkan data yang dikeluarkan oleh Dinas Sosial Kota Medan Januari 2018, bahwa masyarakat Kota Medan yang terdaftar dalam Program Keluarga Harapan (PKH) memiliki sebanya 203 Keluarga Penerima Manfaat (KPM) yang memiliki anggota keluarga penyandang disabilitas. Kondisi penyandang disabilitas yang ada tersebut memiliki berbagai jenis disabilitas. Program Keluarga Harapan yang dicanangkan oleh pemerintah tidak cukup membuat para penyandang disabilitas menjadi mandiri secara ekonomi. Oleh karena itu diharapkan adanya bantuan untuk memberikan ketrampilan terhadap penyandang disabilitas, sehingga para penyandang disabilitas memiliki ketrampilan dan dapat mandiri secara ekonomi. Para penyandang disabilitas yang mendapatkan program PKH dengan indikator memiliki anggota keluarga disabilitas juga terdapat di Kelurahan Suka Damai Kecamatan Polonia. Para penyandang disabilitas ini belum mandiri secara ekonomi dan sangat mengharapkan ada ketrampilan yang bisa disesuaikan dengan jenis kedisabilitasannya.

\subsection{Permasalahan Mitra}

Lurah kelurahan Suka Damai Kecamatan Medan Polonia adalah mitra dari pengabdian ini. Penyandang disabilitas yang ada di wilayah secara ekonomi masih tergantung kepada pihak lain terutama keluarga. Dengan kata lain bahwa penyandang disabilitas yang ada dilayah Kelurahan Sua Damai belum ada yang madiri. Selain itu penerimaan kelurga dan lingkungan 
terhadap penyandang disabilitas masih rendah bahkan ada keluarga yang masih menyembunyikan identitas anggota keluarganya yang menyandang disabilitas. Memberikan penyadaran terhadap masyarakat bahwa penyandang disabilitas memiliki hak yang sama dengan manusia normal lain, dan menghadirkan para penyandang disabilitas ditengah-tengah masyarakat merupakan hal yang harus dilakukan. Disamping itu agar para penyandang disabilitas dapat mandiri secara ekonomi maka diperlukan pelatihan ketrampilan yang bisa membuka peluang mendatangkan materi. Oleh karena itu pelatihan pembuatan papan bunga merupakan solusi bagi para penyandang disabilitas yang memiliki minat. Dengan tujuan para penyandang disabilitas ini bisa membuka usaha jasa papan bunga di bawah pimpinan buk lurah Kelurahan Suka Damai. Lurah Suka Damai dibuat sebagai penanggungjawab atas keberlangsungan usaha papan bungan dengan harapan usaha papan bunga yang angotannya adalah para penyandang disabilitas dapat berkembang dengan baik.

\section{METODE PELAKSANAAN}

Terkait dengan permasalahan dan program yang akan dilakukan untuk mengatasi permasalahan tersebut di atas dan sejalan dengan konsep dan teori pemberdayaan, maka solusi yang diajukan untuk mengatasi dan memecahkan permasalahan tersebut dilakukan dengan metode:

a. Diskusi Kelompok Terfokus (Fokus Group Discussion)

Dalam diskusi kelompok digunakan metode Fokus Group Discussion(FGD). Metode ini dilakukan agar materi diskusi kelompok yang dibahas berfokus pada curah pendapat tentang permasalahan yang dihadapi oleh mitra ( memiliki warga penyandang disabilitas). FGD ini dilakukan dengan menghadirkan penyandang disabilitas, keluarga penyandang disabilitas, kepala lingkungan, pihak kelurahan dan pihak kecamatan. Diadakannya FGD ini disamping untuk menggali permasalahan penyandang disabilitas juga memberikan pemahaman kepada masyarakat yang bukan penyandang disabilatas bahwa perlu menghadirkan penyandang disabilitas disetiap aktivitas di masyarakat dan pemerintah. Membiasakan menghadirkan para penyandang disabilitas di tengah-tengah masyarakat menjadikan masyarakat inklusi.

b. Pelatihan pembuatan papan bunga bagi penyandang disabilitas di Kelurahan Suka Damai

Pelatihan dilakukan bagi penyandang disabilitas dan anggota keluarga lainnya :

a) Memberikan pemahaman kepada anggota keluarga yang memiliki penyandang disabilitas tentang penting para penyandang disabilitas memiliki ketrampilan sehingga penyandang disabilitas memiliki ekonomi secara baik dan mandiri.

b) Persiapan Pelatihan

c) Pemberian peralatan penunjang pelatihan, antara lain:

1) Papan bunga biasa (satu papan);

2) Papan bungan gandeng;

3) Bunga plastik warna merah;

4) Bunga plastik warna putih;

5) Bunga plastik warna orange;

6) Bunga plastik warna kuning

7) Bunga plastik warna hijau;

8) Bunga plastik warna pink;

9) Bunga plastik warna hitam;

10) Bunga plastik warna biru

d) Hal lain yang perlu diperhatikan:

1) Pelatihan pembuatan papan bunga ini memerlukan waktu yg bervariasi berdaarkan jenis kedisabilitasan peserta;

2) Pelatihan pembuatan papan bunga akan disesuaikan dengan waktu para penyandang disabilitas; 
3) Setelah peralatan penunjang pelatihan diserahkan kepada Ibu Lurah Kelurahan Suka Damai secara simbolis, maka selama pelatihan peralatan tersebuat menjadi tanggungjawab pihak kelurahan;

4) Peralatan penunjang pelatihan akan menjadi milik kelompok disabilitas dan lurah kelurahan Suka Damai menjadi penanggungjawab kelompok;

5) Kepala kelurahan dijadikan sebagai penanggungjawab dengan tujuan keberlangsungan dari kelompok papan bungan para disabilitas ini;

6) Para penyandang disabilitas akan diberikan pelatihan pembuatan papan bunga berbagai macam variasi kalimat maupun bentuk;

7) Para penyandang disabilitas akan dilatih membuat papan bunga kecil (satu papan) dan papan bunga gandeng (dua papan).

e) Manfaat media pembelajaran

1) Proses pelatihan lebih sistematik;

2) Proses pelatihan lebih efektif;

3) Proses pelatihan lebih menyenangkan tidak membuat peserta bosan;

4) Motivasi peserta pelatihan lebih meningkat.

\section{HASIL DAN PEMBAHASAN}

\subsection{Hasil Kegiatan}

Hasil pelatihan ini peserta telah mampu membuat papan bunga sesuai pesanan tim pelatih. Dengan adanya pelatihan ini, maka peserta memiliki sumber ekonomi untuk kelanjutan hidup baik sebagai anggota keluarga maupun kepala keluarga.

\subsection{Pembahasan}

Sesuai dengan judul yang diuraikan dalam proposal, sasaran pelatihan pembuatan karangan bunga adalah penyandang disabilitas yang merupakan penduduk wilayah Kecamatan Medan Polonia. Namun, kegiatan ini difokuskan di satu titik, yaitu di aula Kelurahan Sukadamai, Kecamatan Medan Polonia. Berdasarkan kesepakatan, maka mitra dari kegiatan ini adalah lurah Sukadamai. Lurah Sukadamai dijadikan sebagai penanggungjawab kegiatan ini dan keberlanjutan kegiatan ini.

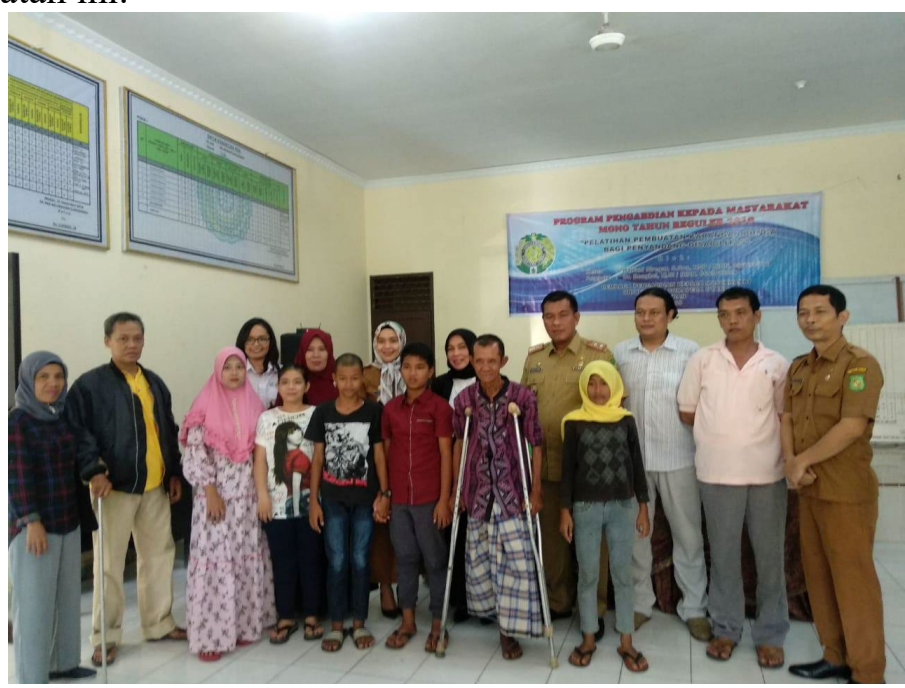

Gambar 1. Foto bersama Camat Medan Polonia, Lurah Sukadamai, penyandang disabilitas, dan keluarganya

Pada gambar 1 para penyandang disabiitas yang akan mengikuti pelatihan pembuatan papan bunga, penyandang disabilitas ini terdiri dari penyandang disabilitas fisik (tangan kiri peserta tidak ada, dan kaki kiri tidak ada) dan tunarungu berjumlah empat orang.

Kemudian, penyerahan alat-alat untuk kegiatan pelatihan pembuatan papan bunga dari ketua tim pengabdian masyarakat kepada Ibu Lurah Sukadamai. 


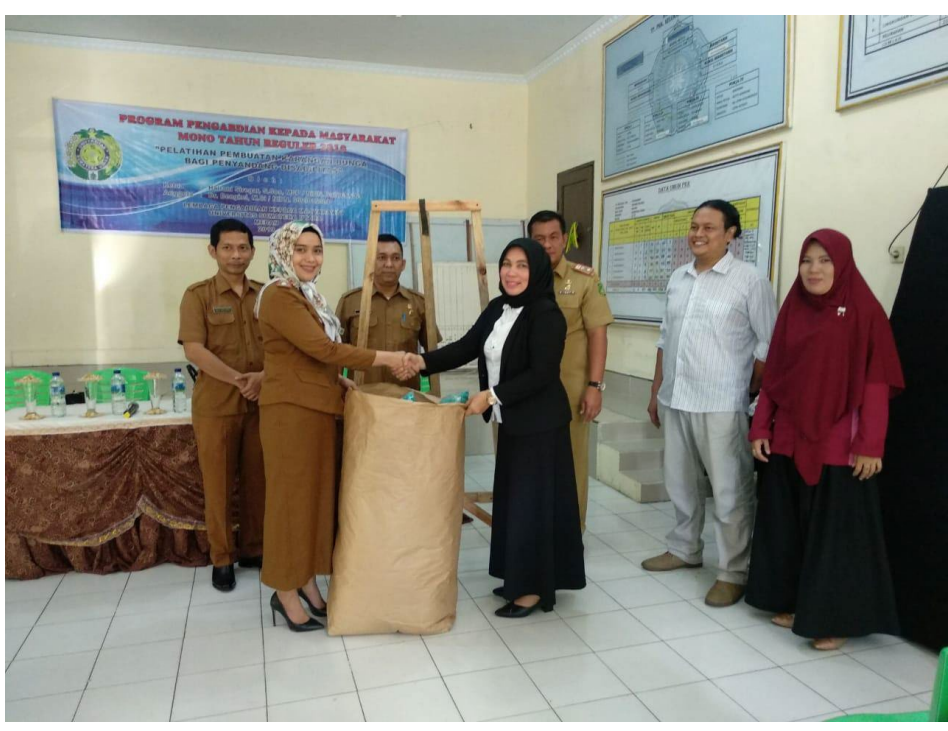

Gambar 2. Penyerahan simbolis alat-alat pelatihan pembuatan papan bunga dari ketua timpengabdian kepada Ibu Lurah Sukadamai

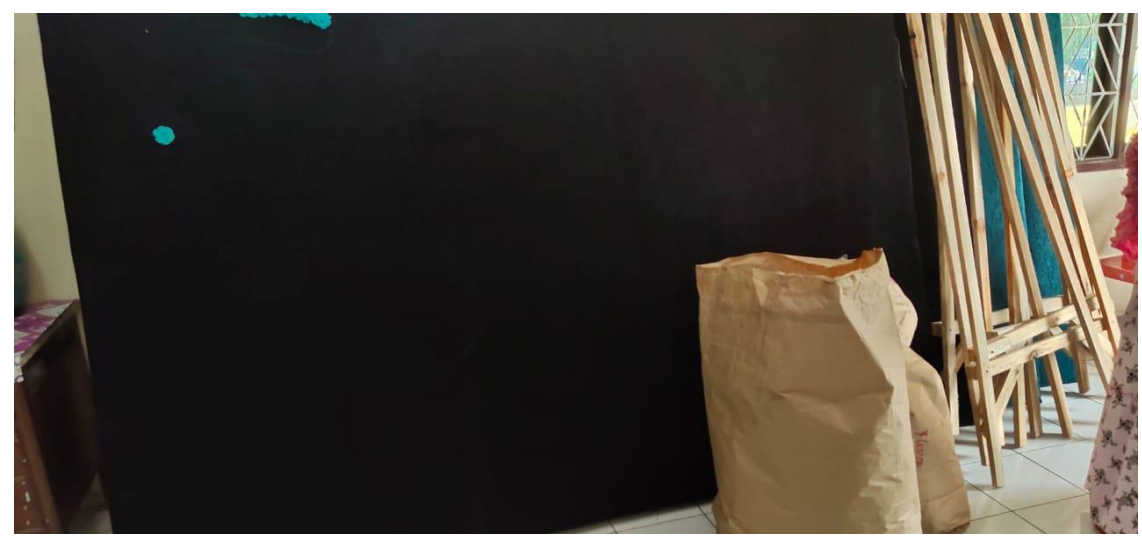

Gambar 3. Papan bunga dan tiang penyangga

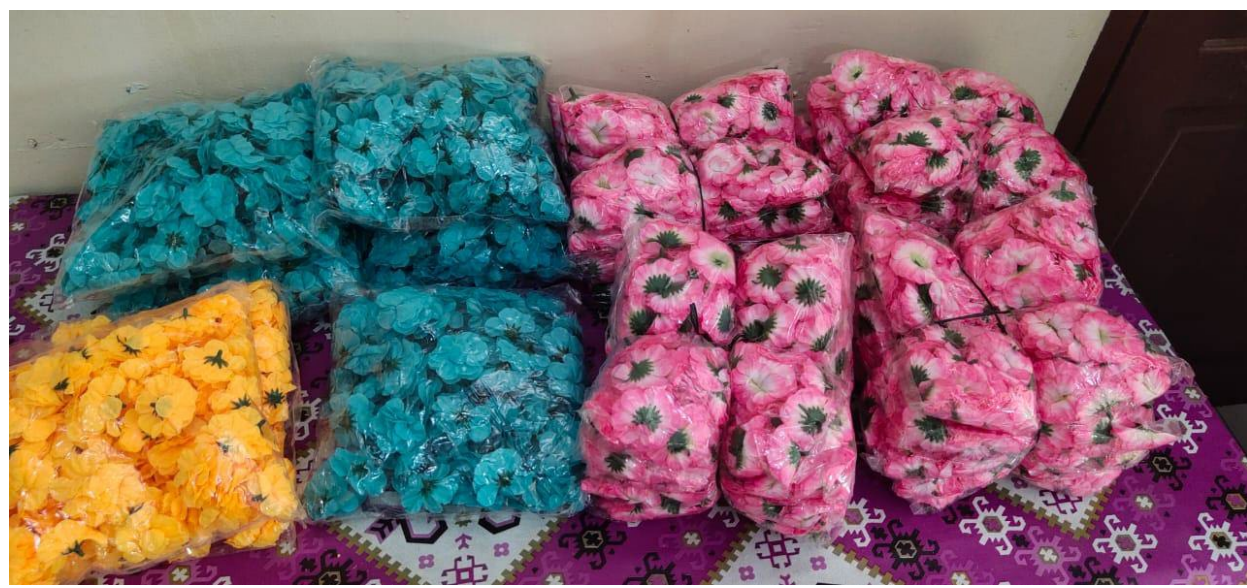

Gambar 4. Bunga berbagai warna 


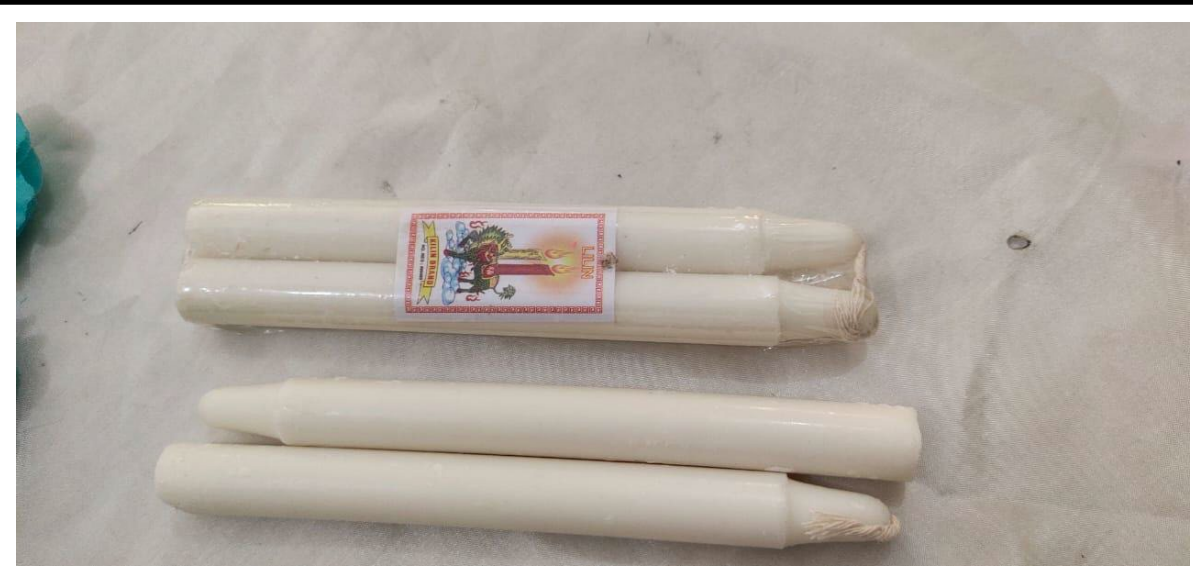

Gambar 5. Alat berupa lilin dan benang

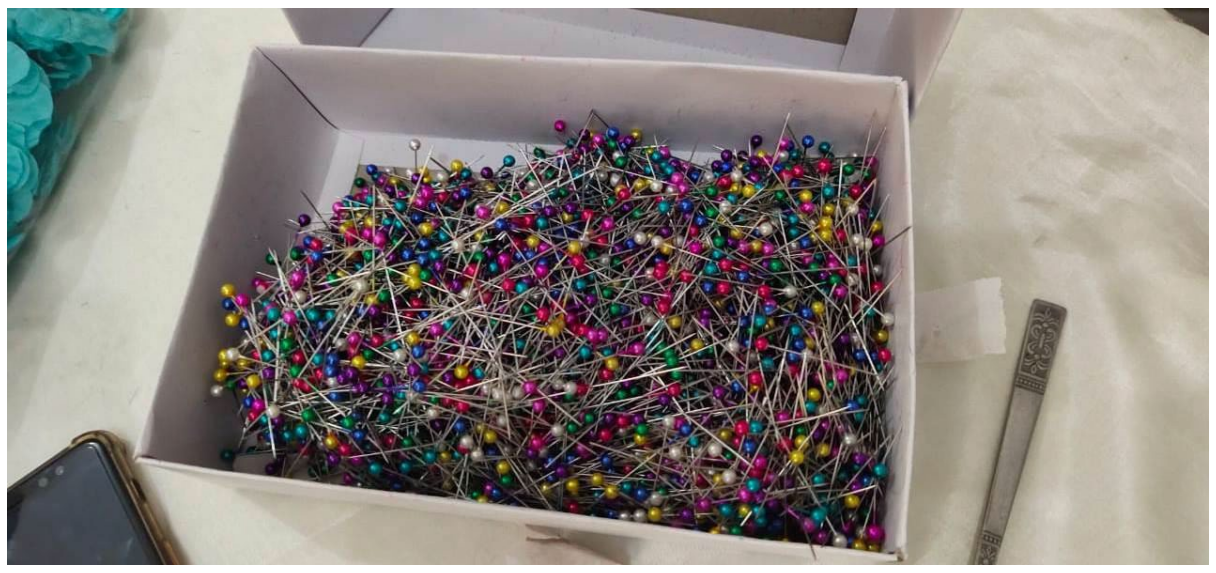

Gambar 6. Peniti sebagai merekatkan bunga di papan

Selanjutnya, pengenalan bahan untuk pembuatan karangan bunga oleh tim pelatih. Pada kesempatan ini tim pelatih menyampaikan manfaat pembelajaran ini karena pelatihan ini bermanfaat untuk menambah penghasilan bagi para penyandang disabilitas.

Selanjutnya, pengenalan bahan untuk pembuatan karangan bunga oleh tim pelatih. Pada kesempatan ini tim pelatih menyampaikan manfaat pembelajaran ini karena pelatihan ini bermanfaat untuk menambah penghasilan bagi para penyandang disabilitas. 


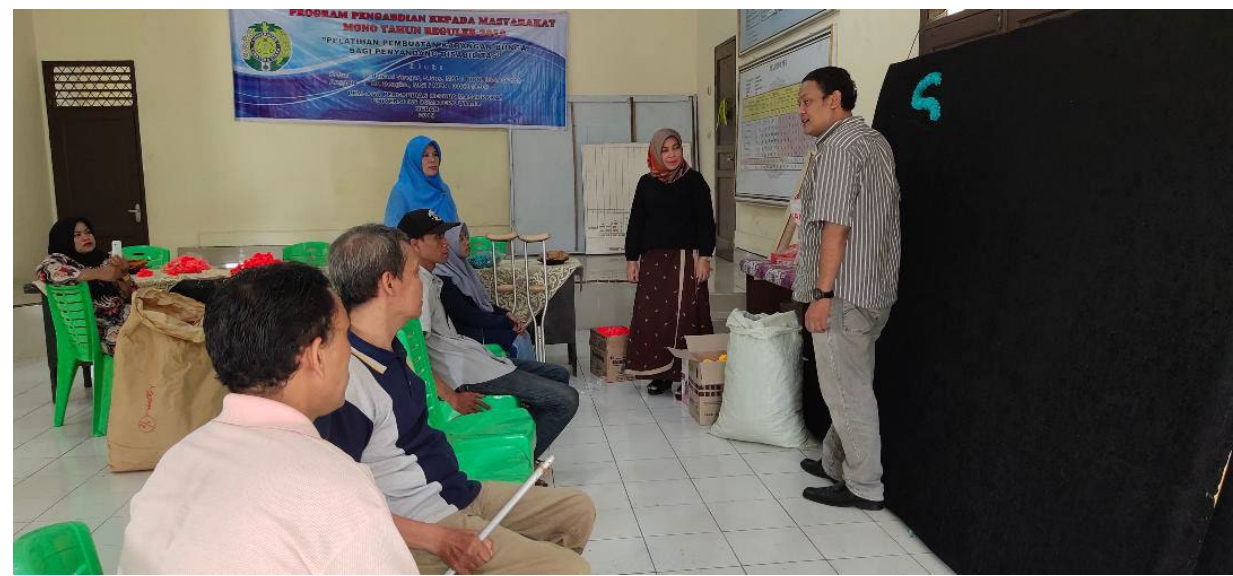

Gambar 7. pengenalan bahan untuk pembuatan karangan bunga oleh tim pelatih

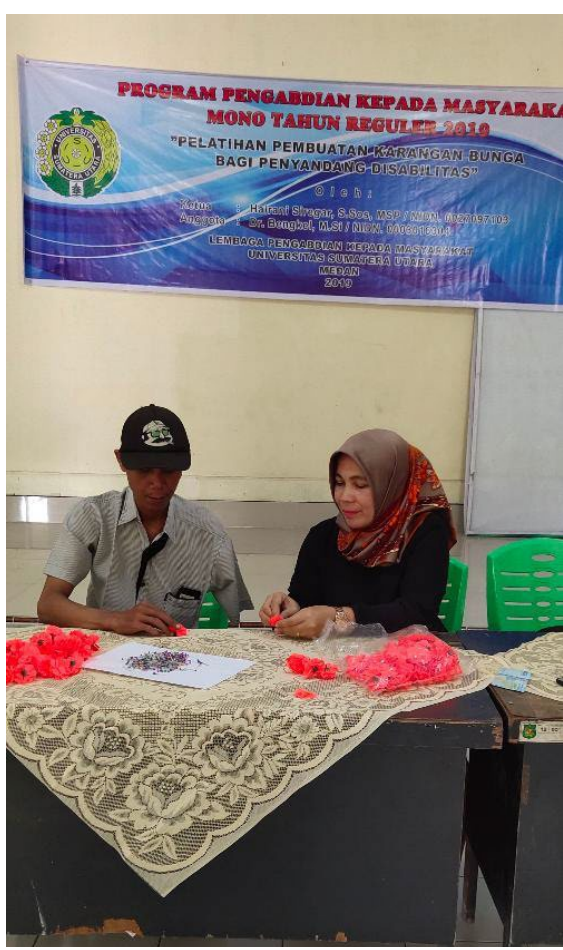

Gambar 8. Tim Pelatih memberi pembelajaran bagi peserta pelatihan 


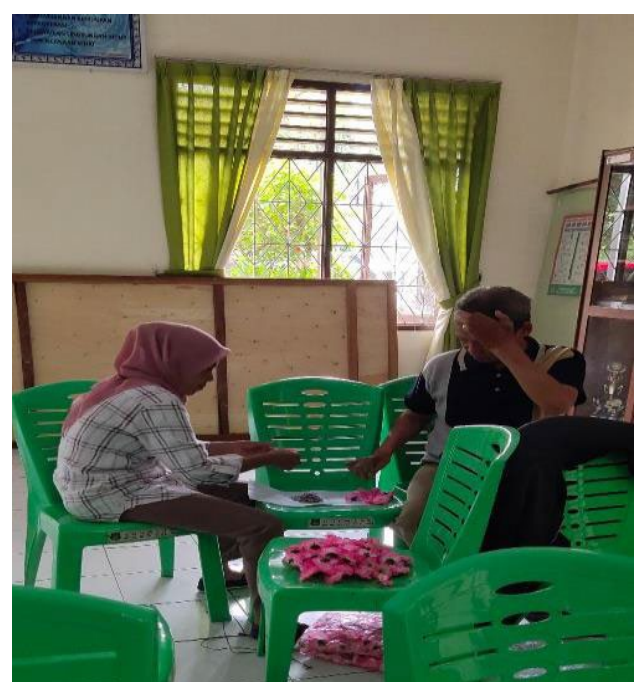

Gambar 9. Peserta latihan untuk menusuk bunga dengan peniti

Tidak hanya diajari untuk menusuk bunga dengan peniti, para peserta juga diajari untuk merangkai bunga pada papan bunga. Terlihat antusias para peserta dalam pelatihan ini. Pada tahap pertama, setelah pengenalan bahan tim pelatih mengajari para peserta untuk mulai membuat karangan bunga. Pada tahap pertama ini peserta diajari untuk menusuk bunga dengan peniti. Peserta menikmati pelatihan ini dengan baik karena seluruh peserta aktif untuk ikut merangkai bunga. Pelatihan berjalan aman dan lancar.

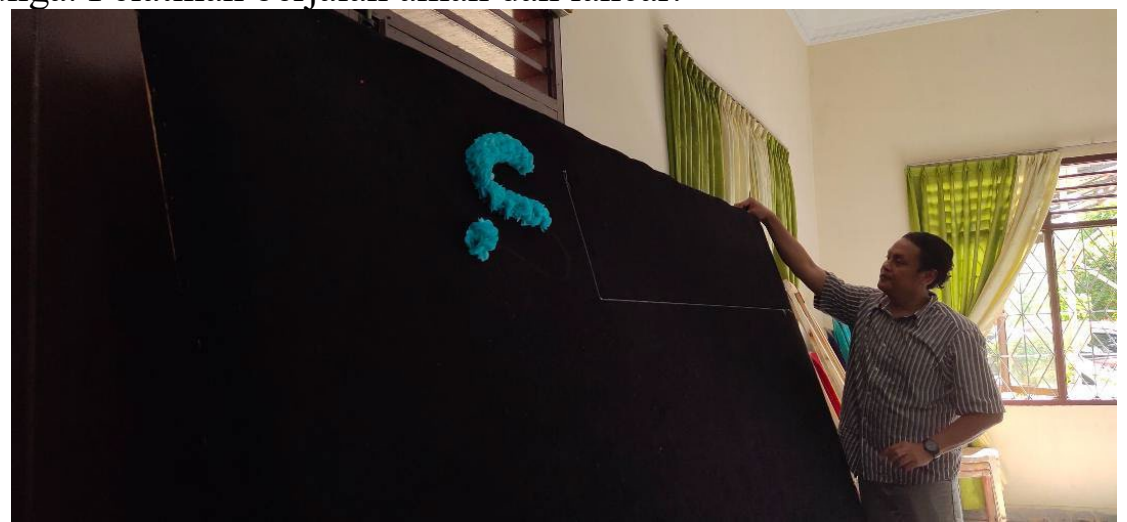

Gambar 10. Tim pelatih mengajari peserta untuk merangkai bunga di papan

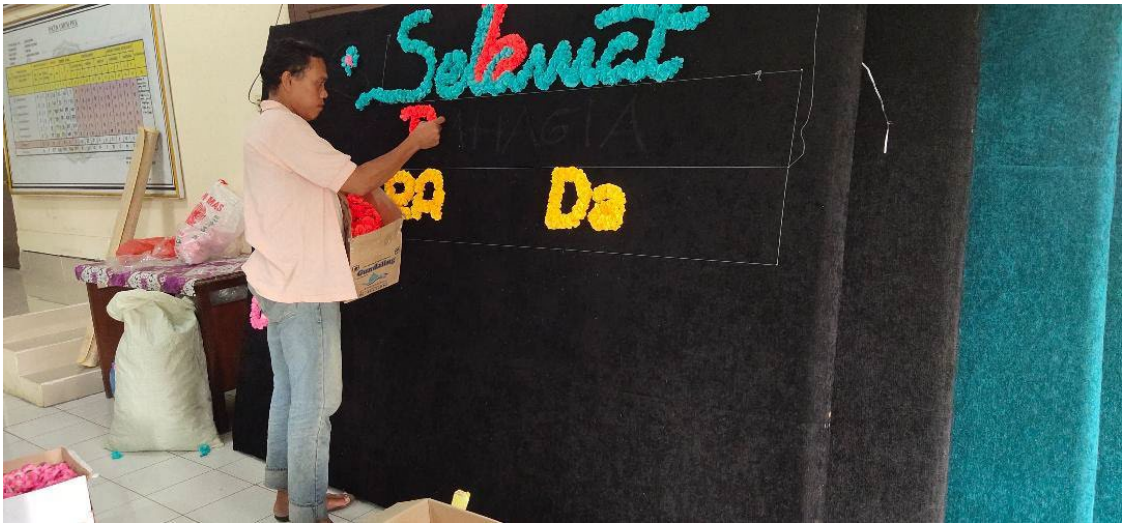

Gambar 11. Peserta berlatih untuk merangkai bunga di papan 


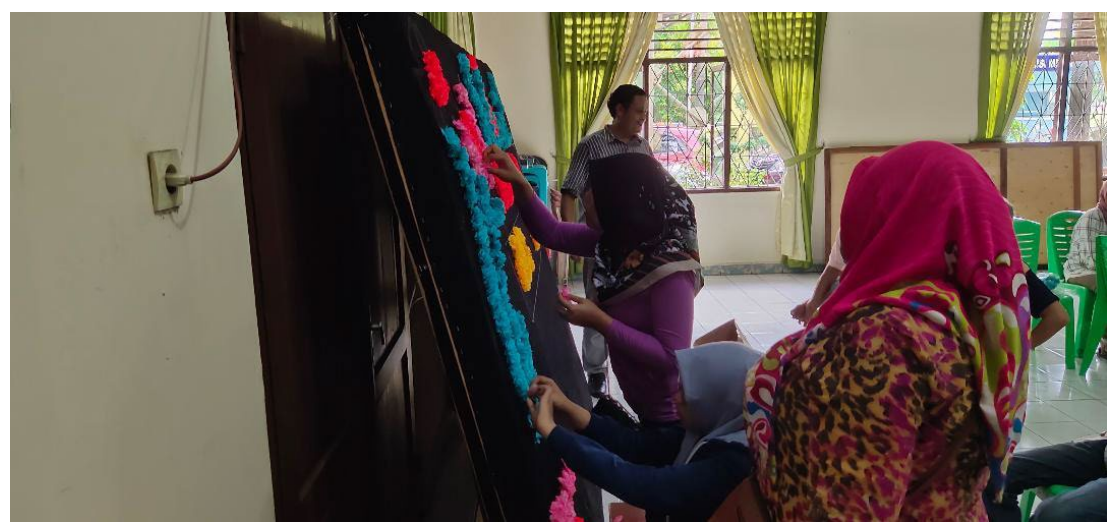

Gambar 12. Para peserta berlatih bersama untuk merangkai bunga di papan

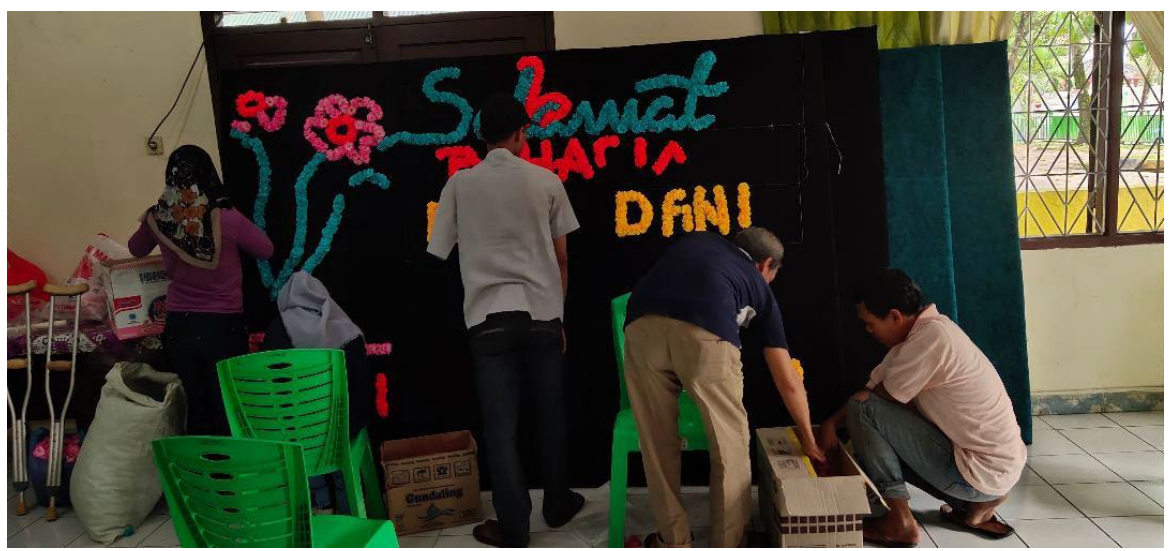

Gambar 13. Para peserta berlatih bersama untuk merangkai bunga di papan

Setelah setiap langkah- langkah kegiatan dilaksanakan, para peserta berhasil merangkai papan bunga.

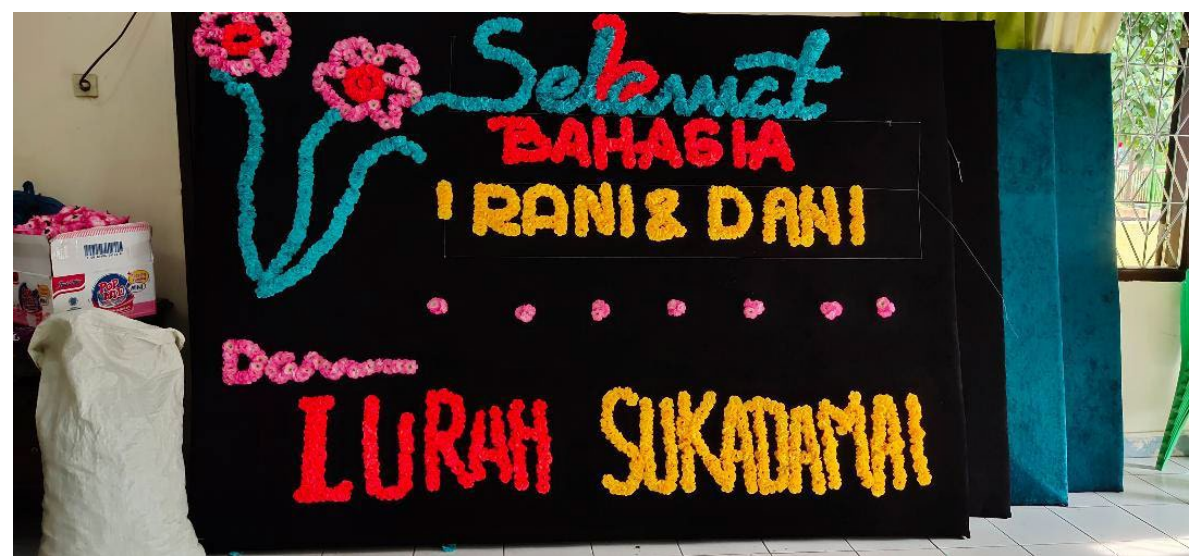

Gambar 14. Papan bunga yang dirangkai oleh para peserta

Hasil pelatihan ini peserta telah mampu membuat papan bunga sesuai pesanan tim pelatih. Dengan adanya pelatihan ini, maka peserta memiliki sumber ekonomi untuk kelanjutan hidup baik sebagai anggota keluarga maupun kepala keluarga. 


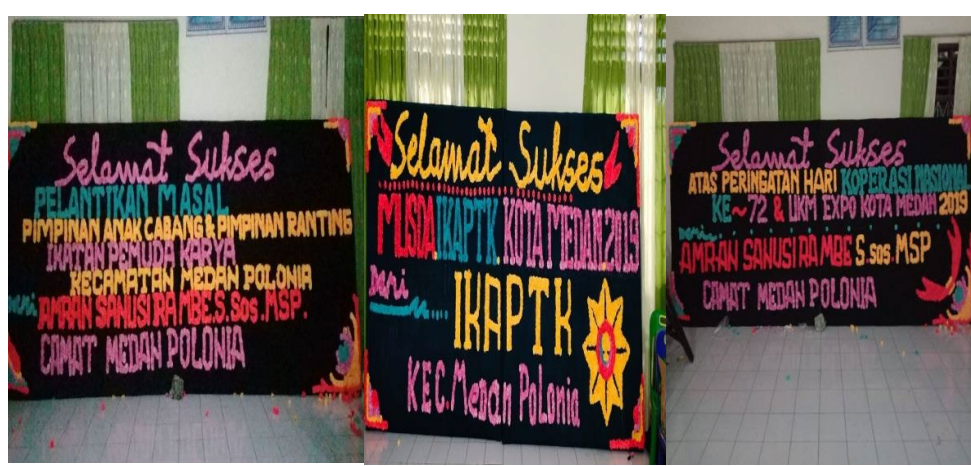

Gambar 15. Contoh beberapa papan bunga yang disiapkan sesuai dengan pesanan konsumen

\section{KESIMPULAN}

Dari kegiatan pelatihan ini panitia pelatihan dapat menyimpulkan bahwa pelatihan ini sangat bermanfaat bagi peserta yang merupakan penyandang disabilitas. Dengan pelatihan perekonomian penyandang disabilitas dapat membaik karena pelatihan ini memberi peluang usaha bagi pesertanya.

\section{UCAPAN TERIMAKASIH}

Ucapan terima kasih kami sampaikan kepada Ketua Lembaga Pengabdian pada Masyarakat Universitas Sumatera Utara, Dekan Fakultas Ilmu Sosial dan Politik, mitra kami, yaitu: Camat Medan Polonia dan Staff Administrasi, Lurah Sukadamai dan staf yang telah membantu kami dalam menyelesaikan kegiatan pengabdian masyarakat ini.

\section{DAFTAR PUSTAKA}

Majda El Muhtaj, 2008 Dimensi-Dimensi HAM Mengurai Hak Ekonomi, Sosial danBudaya, RajaGrafindo Persada, Jakarta

Monika \& Waruwu, 2006 DAN Wasito, Sarwindah, \& Sulistiani, 2010

https://id.wikipedia.org/wiki/Difabel [ONLINE] ( Terakhir Di Akses 20-09-2017 [ 21:54] )

http://www.kemenpppa.go.id/index.php/data-summary/profile-perempuan-indonesia/641-

penyandang-disabilitas [ONLINE] ( Terakhir Di Akses 20-09-2017 [ 21:54] )

http://digilib.unila.ac.id/5849/14/BAB\%20II.pdf [ONLINE] ( Terakhir Di Akses 20-09-2017 [21:55] )

http://erlinaheria.blogspot.co.id/2012/10/penyandang-disabilitas.html [ONLINE] (Terakhir Di Akses 20-09-2017 [ 21:56])

http://teknohere.com/disabilitas-dan-pandangan-masyarakat/[ONLINE] ( Terakhir Di Akses 20-092017 [ 21/:56] ) Majda El Muhtaj, 2008 Dimensi-Dimensi HAM Mengurai Hak Ekonomi, Sosial danBudaya , RajaGrafindo Persada, Jakarta

Monika \& Waruwu, 2006 DAN Wasito, Sarwindah, \& Sulistiani, 2010

https://id.wikipedia.org/wiki/Difabel [ONLINE] ( Terakhir Di Akses 20-09-2017 [ 21:54] )

http://www.kemenpppa.go.id/index.php/data-summary/profile-perempuan-indonesia/641penyandang-disabilitas [ONLINE] ( Terakhir Di Akses 20-09-2017 [ 21:54] )

http://digilib.unila.ac.id/5849/14/BAB\%20II.pdf [ONLINE] ( Terakhir Di Akses 20-09-2017 [21:55] ) http://erlinaheria.blogspot.co.id/2012/10/penyandang-disabilitas.html [ONLINE] (Terakhir Di Akses 20-09-2017 [ 21:56] )

http://teknohere.com/disabilitas-dan-pandangan-masyarakat/[ONLINE] ( Terakhir Di Akses 20-092017 [ 21/:56] ) 